\title{
Age of the
}

\section{Skooner Gulch}

Formation, Mendocino County, California

By WARREN O. ADDICOTT

C O N T R I B U TIO N S TO S TRATIGR A P H Y

GE OLOGICAL S URVEY B ULLETIN $1254-\mathrm{C}$

Early Miocene mollusks from the Skooner Gulch Formation near Point Arena mark a significant northward extension of the warm water "Vaqueros" fauna

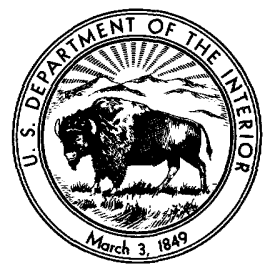




\section{UNITED STATES DEPARTMENT OF THE INTERIOR}

STEWART L. UDALL, Secretary

\section{GEOLOGIGAL SURVEY}

William T. Pecora, Director

U.S. GOVERNMENT PRINTING OFFICE, WASHINGTON : 1967 


\section{CONTENTS}

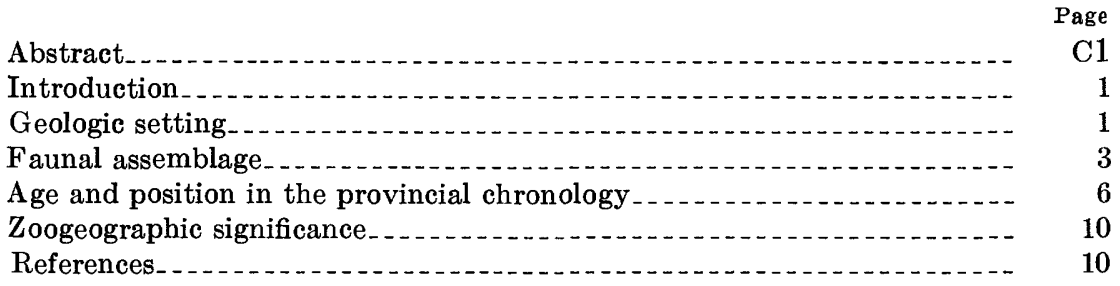

\section{ILLUSTRATIONS}

Figure 1. Index map of Schooner Gulch area

2. Photograph showing contact between Skooner Gulch Formation and Iversen Basalt . . . . . . . . . . . . . . . . . . . .

3. Photograph showing contact between Skooner Gulch and

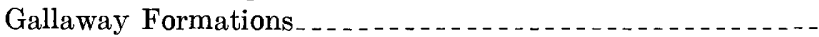

4. Illustrations of fossils from the Skooner Gulch Formation and Jewett Sand 



\title{
CONTRIBUTIONS TO STRATIGRAPHY
}

\section{AGE OF THE SKOONER GULGH FORMATION MENDOCINO COUNTY, GALIFORNIA}

\author{
By Warren O. Addicott
}

\begin{abstract}
Newly discovered mollusks from the Skooner Gulch Formation near Point Arena, Calif. (lat $38.9^{\circ} \mathrm{N}$.) are indicative of an early Miocene age. Included are Turritella inezana forma hoffmanni Gabb and Chlamys cf. C. hertleini Loel and Corey, species restricted to the "Vaqueros Stage"-the standard for the early Miocene of the provincial megafaunal chronology. The Skooner Gulch assemblage marks a significant northward extension of the warm water "Vaqueros" fauna from localities in the Santa Cruz Mountains (lat $37.4^{\circ}$ N.).
\end{abstract}

\section{INTRODUCTION}

Marine Miocene megafossils from the Skooner Gulch Formation, a 200- to 300-foot sandstone unit occurring at the base of a 4,700-foot marine Miocene shale and mudstone sequence near Point Arena, Mendocino County, Calif., provide the first direct evidence of age of this formation and in addition are a significant new tie between the Pacific coast molluscan and foraminiferal chronologies. Weaver (1944, p. 4, pl. 11) named and first mapped this formation; although no fossils were found, its age was considered to be Oligocene. Mollusks from it (USGS Cenozoic loc. M2494) were submitted for identification and age determination by E. H. Stinemeyer in June 1965. These specimens, plus additional material collected by the writer in November 1965 (USGS Cenozoic loc. M2638), have yielded a small but significant molluscan assemblage that is recorded here for the first time. Previously unreported marine mammal remains of Miocene age from near the top of the formation are of further use in determining position in the provincial marine chronologies.

\section{GEOLOGIC SETTING}

Cretaceous and Tertiary marine clastics crop out in a narrow coastal strip west of the San Andreas fault from Fort Ross, about 65 miles 
northwest of San Francisco, northward to Point Arena. Seacliff and intertidal zone exposures of the Upper Cretaceous to Miocene rocks of this 40-mile belt were mapped by planetable by Weaver (1944, scale, $1 \mathrm{in.}=1,000 \mathrm{ft}$ ). Recently completed mapping of this area (Wentworth, 1966 ) is incorporated into the index map showing the type area of the Skooner Gulch Formation and the fossil localities (fig. 1).

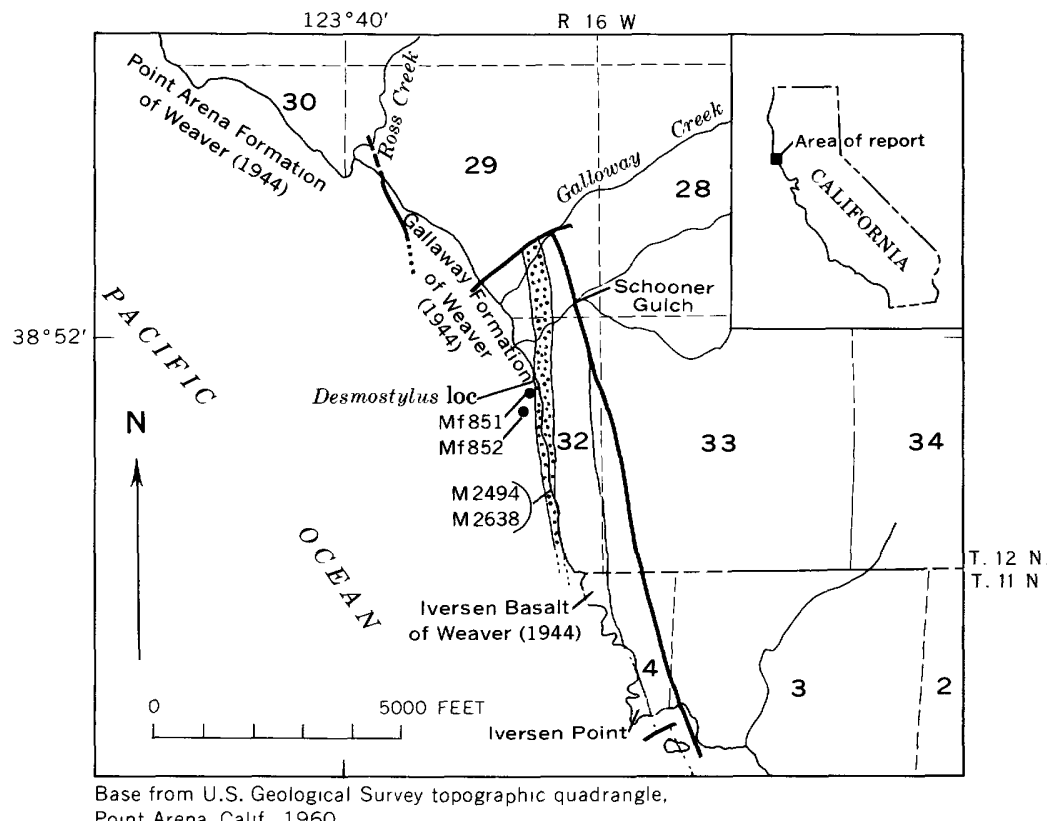

FIGURE 1.-Map of Schooner Gulch area, Mendocino County, Calif., showing relationship of Skooner Gulch Formation (stippled) to Miocene formations. Geology compiled from Weaver (1944) and Wentworth (written commun., April 1966).

Overlying the older part of the section mapped as the Gualala Group by Weaver (1944), about 8 miles southeast of Point Arena, is an 800foot unit of amygdaloidal basalt (fig. 2) originally named the Skooner Gulch Basalt by Weaver (1943), but later renamed the Iversen Basalt by Weaver (1944). Unconformably overlying the basalt are mediumto coarse-grained massive sandstones that Weaver originally (1943) included in the basal part of his Galaway Beds but which he later (1944) named the Skooner Gulch Formation. ${ }^{1}$ The type locality of the

\footnotetext{
1 Although the spelling of the place name has subsequently been corrected to Schooner Gulch, Weaver's (1944) spelling of the formation is retained (see Article 12a, 1961 Code of Stratigraphic Nomenclature).
} 
formation is here designated as the seacliff and intertidal exposures in the east half of sec. 32, T. 12 N., R. 16 W. The basal contact is best exposed in seacliffs about two-thirds of a mile south of the mouth of Skooner Gulch (fig. 2). The basal foot or so consists of a very hard greenish-gray calcareous sandstone containing scattered poorly preserved mollusks. The contact of the Skooner Gulch with the overlying Gallaway Formation of Weaver (1944) is clearly exposed (fig. 3) in the intertidal zone about a quarter of a mile south of Schooner Gulch where the formation is about 200 feet thick. In this area it is placed at the highest stratigraphic occurrence of brown glauconitic fine-grained sandstone and is marked by a wave-resistant bench standing higher in the intertidal zone than the overlying gray weathering foraminiferal mudstone of Weaver's Gallaway Formation which is planed-off into a broad reef exposed only during low tide (fig. 3). Near the mouth of Schooner Gulch the contact between the Skooner Gulch and Gallaway Formations appears to be gradational. Farther south, however, the glauconitic and phosphatic sandstones of the upper part of the Skooner Gulch Formation are progressively truncated by the overlying gray weathering sandy mudstones of the Gallaway Formation. The southernmost exposures of the formation in the intertidal zone at a small cove about 3,500 feet south of Schooner Gulch are only about 20-30 feet thick. The Gallaway consists of about 1,200 feet of foraminiferal mudstone with interbedded sandstone and concretionary strata.

The Iverson Basalt of Weaver (1944) and the overlying sandstone and foraminiferal mudstone of the Skooner Gulch and Gallaway Formations form a simple westward-dipping homoclinal structure in the vicinity of Schooner Gulch that is broken only by minor faults. Excellent continuous exposures of these formations crop out in seacliffs and in the intertidal zone from Iverson Point northward for about 2 miles to near Ross Creek (fig. 1). This stretch includes the type areas for each of the formations.

\section{FAUNAL ASSEMBLAGE}

Marine megafossils occur in a seacliff 6-12 feet above a gravel beach about two-thirds of a mile south of Schooner Gulch (USGS Cenozoic locs. M2494 and M2638) at the base of massive sandstone mapped as the Skooner Gulch Formation by Weaver (1944). The locality (fig. 2) is accessible only during a low tide. Poorly preserved mollusks, principally turritellas and small pectinids, are scattered in a 6- to 12 -inch bed of light-greenish-gray poorly sorted sandstone that unconformably overlies the Iverson Basalt of Weaver (1944). A few hundred feet 


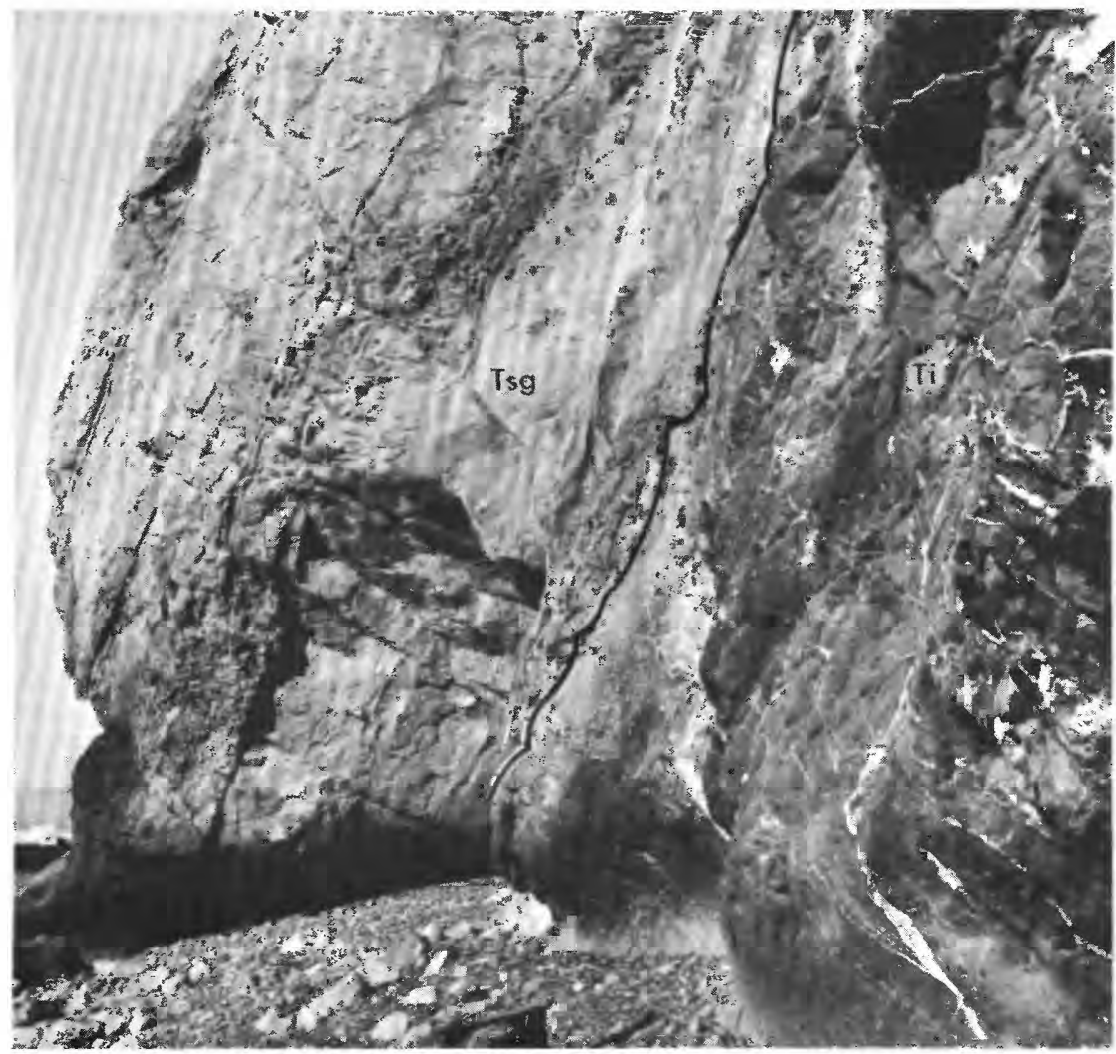

Figure 2.-Contact between the Skooner Gulch Formation (Tsg) and the underlying Iversen Basalt (Ti) of Weaver (1944) in seacliff about 3,000 feet south of mouth of Schooner Gulch. USGS Cenozoic locs. M2494 and M2638 are at the very base of the Skooner Gulch Formation about 6-12 feet above the gravel beach.

farther south the basal sandstone contains closely packed valves of very poorly preserved, indeterminate pelecypods.

Near the top of the Skooner Gulch Formation is a 15-foot interval of fine-grained glauconitic sandstones with abundant nodules of phosphatic material up to 3 inches in diameter. Scattered shark teeth, fish vertebrae, and bone fragments occur in these uppermost fine-grained sandstones. A cheek tooth of Desmostylus (identified by C. A. Repenning, oral commun., Oct. 1966) has also been collected from near the top of the formation.

The molluscan assemblage from the base of the Skooner Gulch Formation consists of Turritella inezana forma hoffmanni Gabb, Chlamys cf. $C$. hertleini Loel and Corey, Chlamys aff. $C$. mollita (Reeve), Lucinoma sp., a large cardid, and locally abundant, undetermined 


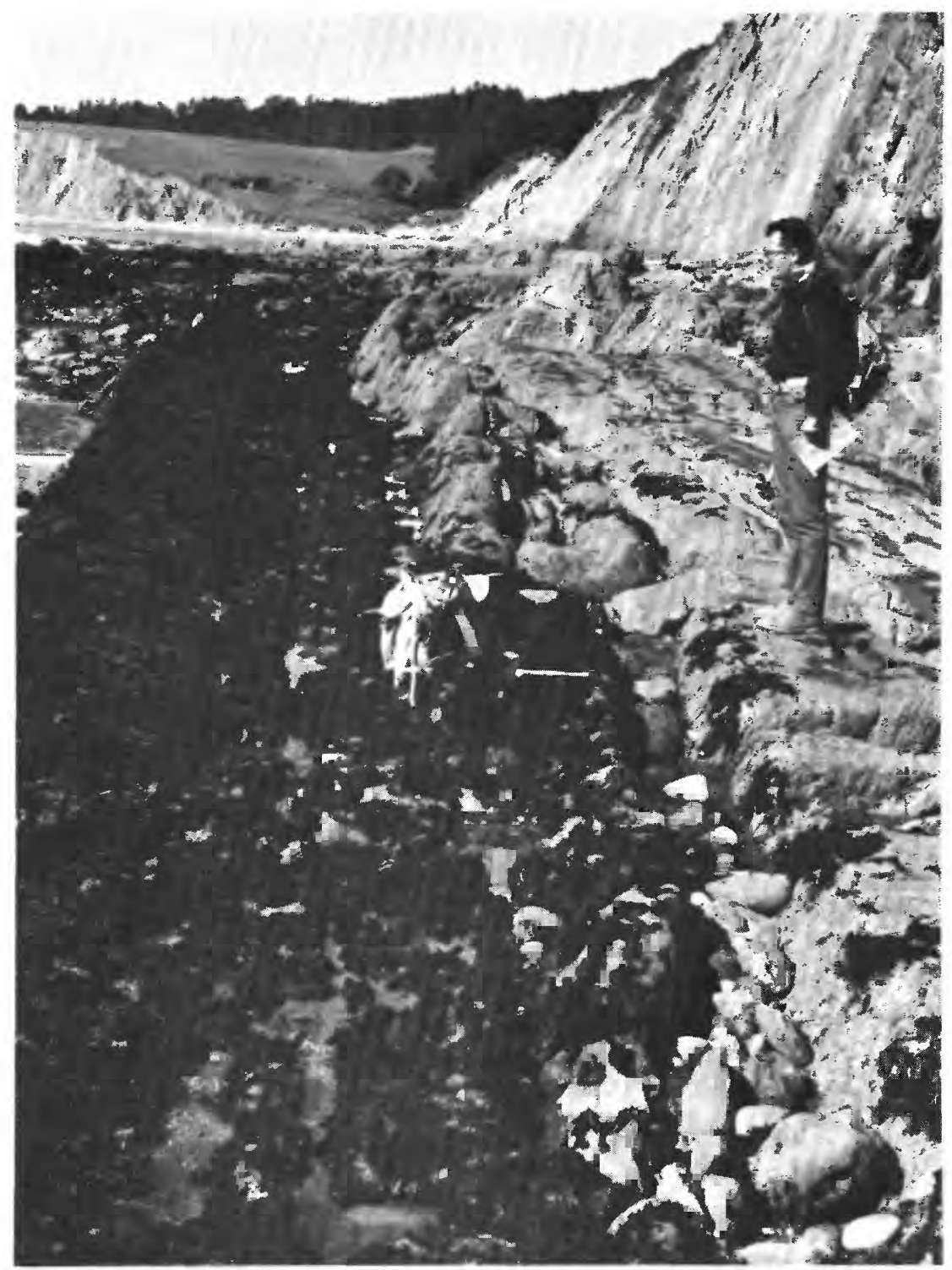

Figure 3.-Contact between the Skooner Gulch Formation and the overlying Gallaway Formation of Weaver (1944) in intertidal zone about a quarter of a mile south of Schooner Gulch. Knapsack is lying on contact separating glauconitic fine-grained sandstone of the upper part of the Skooner Gulch Formation from algae-covered sandy mudstone of the basal part of the Gallaway Formation. 
thick-shelled pelecypods. There are also numerous burrows, one-half to three-fourths of an inch in diameter, oriented normal to the bedding. The pectinids and Turritella are illustrated in figure 4.

Turritella inezana forma hoffmanni is represented by a few fairly well preserved specimens, the better preserved of which are illustrated in figure 4. These specimens have been compared with material collected near the type locality of this form in the Santa Cruz Mountains, about 140 miles to the south of Point Arena (USGS Cenozoic loc. M2002). Several additional specifically indeterminate turritellas were collected from the locality.

Although doubtfully identified, specimens of Chlamys cf. $C$. hertleini are very similar to specimens of $C$. hertleini from central California; the degree of resemblance can be seen in figures $4 A, B, D, G$.

A very finely ribbed pectinid, unlike any known Tertiary species from the northeastern Pacific Ocean (fig. 4C), resembles the early Pliocene to Recent Chlamys mollita (Reeve) (Masuda, 1962, pl. 21, fig. 7; pl. 23, figs. 6-8) from Japan. Chlamys mollita is a shallow-water species, 5-10 fathoms (Kira, 1962, p. 121), which lives along the Pacific coast of Japan from $31^{\circ}$ to $35^{\circ} \mathrm{N}$. and in the Sea of Japan (Masuda, 1962).

\section{AGE AND POSITION IN THE PROVINCIAL CHRONOLOGY}

Turritella inezana forma hoffmanni and Chlamys cf. $C$. hertleini suggest correlation with the "Vaqueros Stage" of the Pacific coast megafaunal chronology (Weaver and others, 1944). The "Vaqueros Stage" is considered early Miocene by molluscan paleontologists although some microfossil specialists prefer to call it Oligocene.

The range of Turritella inezana is regarded as coextensive with the "Vaqueros Stage" by megafossil workers (Loel and Corey, $19322^{2}$; Eaton and others, 1941; Weaver and others, 1944), and this has long been used as the principal index fossil for this chronostratigraphic unit in California. The subgeneric group to which this species is assigned first appears in rocks of "Vaqueros" age in California (Merriam, 1941). It is a distinctly different lineage from the Pacific coast Oligocene turritellas. The variety $T$. inezana forma hoffmanni is closely related to $T$. inezana ss.; it was included in the synonymy of that taxon by Loel and Corey (1932). Occurrences of this form within the "Vaqueros Stage" range from what is considered the lower part in the

a This is the definitive report on the "Vaqueros Stage." Although these authors did not use the term "stage," their treatment of their Vaqueros Formation or Vaqueros Horizon is more nearly that of a time-stratigraphic unit rather than a rock-stratigraphic unit. Quotation marks are used herein to distinguish the Vaqueros Stage of the Pacific coast megainvertebrate time-stratigraphic classification of Weaver and others (1944) from the Vaqueros Formation. 
Caliente Range of eastern San Luis Obispo County, Calif. (Eaton and others, 1941) to fairly high in the lower Mioce re sequence in the Temblor Range of northwestern Kern County (Crrneros Sandstone Member of the Temblor Formation of Cunningham and Barbat, 1932; USGS Cenozoic locs. M2623 and M2627).

Fragmentary specimens of a Chlamys from USC $S$ Cenozoic locality M2638 are similar to specimens of $C$. hertleini Lcel and Corey (fig. $4 B, D$ ) from localities in Kern County, Calif. Thз fragments have weakly imbricate primary ribs that alternate with fine secondaries (fig. $4 A, G$ ). Chlamys hertleini is also restricted to the "Vaqueros Stage." Loel and Corey (1932, p. 138) originally indicated its range as restricted to their middle zone but subsequent evid'nce has extended its range to the upper part of the "Vaqueros Stage" (Addicott, 1965).

Foraminifera have not been found in the Skooner Gulch Formation. Microfossil samples collected by the writer from the lower part of the overlying Gallaway Formation of Weaver (1944), about 20 feet and 220 feet above the glauconitic sandstone at the top of 1 he Skooner Gulch Formation (USGS locs. Mf851 and Mf852), cor tain fairly large faunules referred to the Zemorrian Stage of Kleinpe 1 (1938) by Patsy J. Smith (written commun., Dec. 1965). The lowes sample (Mf851) contained the following species listed by Kleinpell 1938, p. 137-151) as restricted to the lower part of his Zemorrian Stige: Nonion affine (Reuss), N. ynezianum Kleinpell, Valvulineria casi iasensis subcasitasensis Kleinpell, Eponides frizaelli Kleinpell, an l Cibicides pseudoungerianus evolutus Cushman and Hobson. '.'The stratigraphic ranges of two of these species, Nonion affine and Cibicides pseudoungerianus evolutus, as well as the range of the zonal index, Uvigerina gallowayi, have subsequently been extended upwa:d into the lower part of the Saucesian Stage (Kleinpell and Weaver, 1933, p. 39). Foraminifera of the lower Zemorrian Uvigerina gallownyi zone were first reported from localities 50-175 feet stratigraphically above the base of the Gallaway Formation on the north side of the routh of Schooner Gulch and from a 210-foot interval in the Gallavray Formation at Ross Creek about a mile to the northwest (Kleinpell, 1938, p. 76). Additional collections from the Gallaway and from the lower part of the overlying Point Arena Formation were identified yy Weaver (1944, p. 23-25) but were not correlated with the Pacific soast microfaunal sequence.

From the stratigraphic relationships of Turrite la inezana forma hoffmanni from the Skooner Gulch Formation to Joraminifera from the lower part of the overlying Gallaway Formation it is clear that the biozone of Turritella inezana includes strata that have been classified as lower Zemorrian. Although this seems to be the first record of 


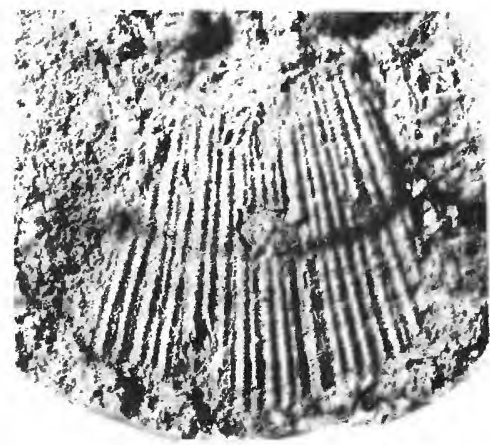

A

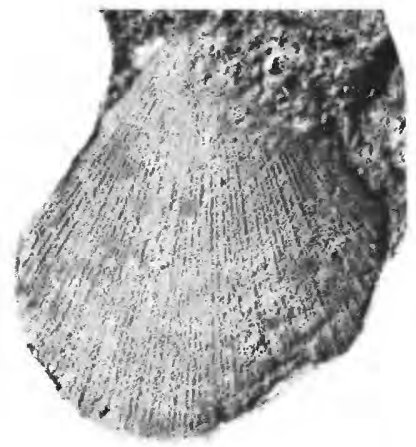

C

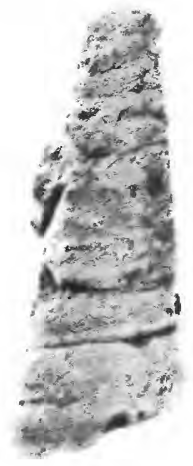

$E$

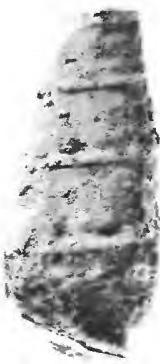

$F$

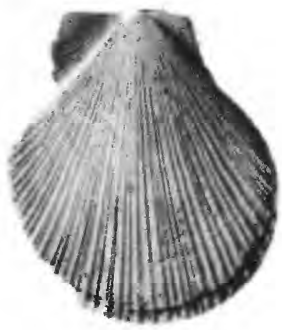

$B$
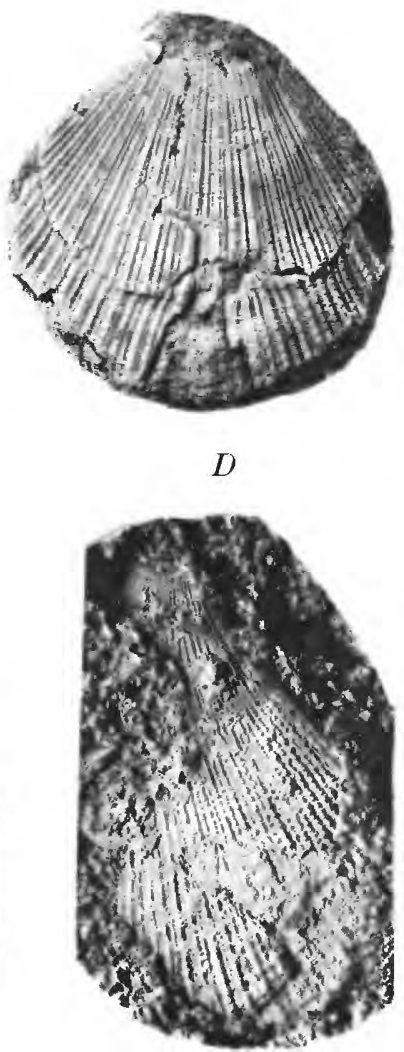

$G$

Figure 4-Mollusks from the Skooner Gulch Formation, Mendocino County, and Jewett Sand of Godde (1928), Kern County, Calif. (Explanation on opposite page.) 
$T$. inezana occurring with or below lower Zemorrian foraminifers, other molluscan guides to the "Vaqueros Stage" such as Lyropecten magnolia and Ostrea vaquerosensis occur stratigraphically below lower Zemorrian microfossils in the central California Coast Ranges a few miles northeast of Santa Maria (Kleinpell, 1938, p. 73, fig. 14; Loel and Corey, 1932, p. 102-103).

The significance of the apparent range extension of $T$. inezana indicated by its occurrence stratigraphically below foraminifera referable to the lower part of the Zemorrian Stage seems to be clouded somewhat by indications that the lower part of the Zemorrian Stage is in need of redefinition (Rothwell, 1965). Moreover, Kleinpell and Weaver (1963, p. 37) stated that in some parts of central California a deep-water facies of the Zemorrian may have persisted into Saucesian time. The age of the Gallaway Formation may be affected by this revision as Kleinpell and Weaver (1963, p. 43) indicate a "Zemorrian and (or) lower Saucesian" age; however, on their correlation chart (fig. 5) an early Zemorrian to early Saucesian age is indicated for the "Galloway Beds of the Mendocino Coast." After examining foraminiferal assemblages and previously reported faunal lists from the basal part of the Gallaway Formation, Richard Pierce (written commun., Dec. 1966) concluded that the presence of Siphogenerina multicostata Cushman and Jarvis in the samples (Kleinpell, 1938, p. 76) is more suggestive of late Zemorrian or Saucesian than of early Zemorrian age.

A cheek tooth of Desmostylus, collected by the writer and Richard Pierce 12 feet below the top of the Skooner Gulch Formation (USGS vertebrate loc. M1114), is compatible with the molluscan evidence of an early Miocene age for the formation. The well-documented strati-

A. Chlamys cf. C. hertleini Loel and Corey. $\times 2$. USNM 649592, a rubber cast. Basal part of Skooner Gulch Formation, USGS Cenozoic loc. M2638.

B. Chlamys hertleini Loel and Corey. $\times 1$. UCLA 33491.

"Top of Pyramid Hill Sand" [Jewett Sand of Addicott (1965)], Kern County, Calif., UCLA loc. MB 2000.

C. Chlamys aff. C. mollita (Reeve). $\times 2$. USNM 649593, a rubber cast.

Same locality as $A$.

D. Chlamys hertleini Loel and Corey. $\times 1$. UCMP 32254 .

About 170 feet above base of Jewett Sand of Godde (1928), Kern County, Calif., UCMP loc. B1654.

E. Turritella inezana forma hoffmanni Gabb. $\times 1 \frac{1}{2}$. USNM 649594.

Same locality as $A$.

F. Turritella inezana forma hoffmanni Gabb. $\times 1$. USNM 650329.

Basal part of the Skooner Gulch Formation, USGS Cenozoic loc. M2494.

G. Chlamys ef. C. hertleini Loel and Corey. $\times 2$. USNM 649595, a rubber cast.

Same locality as $A$. 
graphic range of this marine mammal (Mitchell and Repenning, 1963) extends from the "Vaqueros Stage" to the "Neroly Stage" of the molluscan chronology and from the lower Saucesian to the lower Delmontian of the microfossil chronology.

\section{ZOOGEOGRAPHIC SIGNIFICANCE}

The occurrence of a variant of Turritella inezana near Point Arena lat $38.9^{\circ} \mathrm{N}$.) is a significant northward extension of this species' geographic range from localities in the Santa Cruz Mountains (lat $37.4^{\circ}$ N.), ${ }^{3}$ (Gabb, 1866; Arnold, 1906). It also marks the northernmost occurrence of the subgenus Torcula (the Turritella altilira stock of Merriam, 1941), a taxonomic unit that is essentially tropical in its modern distribution in the eastern Pacific Ocean. The occurrence of this subgenus near Point Arena suggests that a subtropical shallowwater marine climate occurred at least this far north during the biochron of Turritella inezana. The small pectinids are compatible with this interpretation. Chlamys hertleini occurs in warm water "Vaqueros" assemblages elsewhere in California. The northwestern Pacific Ocean species $C$. mollita, with which another pectinid is compared, lives in a shallow-water subtropical province off the east coast of Japan.

\section{REFERENCES}

Addicott, W. O., 1965, Miocene macrofossils of the southeastern San Joaquin Valley, California, in Geological Survey Research 1965: U.S. Geol. Survey Prof. Paper 525-C, C101-C109, 4 figs.

American Committee on Stratigraphic Nomenclature, 1961, Code of Stratigraphic Nomenclature: Am. Assoc. Petroleum Geologists Bull., v. 45, no. 5, p. 645-665.

Arnold, Ralph, 1906, The Tertiary and Quaternary pectens of California: U.S. Geol. Survey Prof. Paper 47, 264 p., 53 pls.

Cunningham, G. M., and Barbat, W. F., 1932, Age of the producing horizon at Kettleman Hills, California: Am. Assoc. Petroleum Geologists Bull., v. 16, no. 4, p. 417-421.

Eaton, J. E., Grant, U.S., 4th, and Allen, H. B., 1941, Miocene of Caliente Range and environs, California: Am. Assoc. Petroleum Geologists Bull., v. 25, no. 2, p. 193-262.

Gabb, W. H., 1866, Tertiary invertebrate fossils, in Paleontology : California Geol. Survey, v. 2, sec. 1, pt. 1, p. 1-38.

Godde, H. A., 1928, Miocene formations in the east side fields of Kern County : California Oil Fields, v. 14, no. 1, p. 5-15.

Kira, Tetsuaki, 1962, Coloured illustrations of the shells of Japan : Osaka, Japan, Hoikusha, 239 p., 71 pls. [In Japanese.]

A record of this species from USGS locality $\mathbf{5 4 5 0}$ on the Umpqua River, Douglas County, Oreg., by Dall (in Washburne, 1914) is believed to be a misidentification or otherwise in error because this locality is in the type section of the middle Eocene Tyee Formation (Turner, 1938, p. 19). 
Kleinpell, R. M., 1938, Miocene stratigraphy of California: Tulsa, Okla., Am. Assoc. Petroleum Geologists, $450 \mathrm{p}$.

Kleinpell, R. M., and Weaver, D. W., 1963, Oligocene biostratigraphy of the Santa Barbara embayment, California : California Univ., Pubs. Geol. Sci., v. 43, 250 p., 38 pls.

Loel, Wayne, and Corey, W. H., 1932, The Vaqueros formation, lower Miocene of California ; I, Paleontology : California Univ., Dept. Geol. Sci. Bull., v. 22, no. 3 , p. 31-410, pls. $4-65$.

Masuda, Koichiro, 1962, Tertiary Pectinidae of Japan: Tohoku Univ. Sci. Repts., ser. 2 (geology), v. 33, no. 2, p. 117-237, pls. 18-27.

Merriam, C. W., 1941, Fossil Turritellas from the Pacific Coast Region of North America : California Univ., Dept. Geol. Sci. Bull., v. 26, no. 1, 214 p., 41 pls., 19 figs.

Mitchell, E. D., Jr., and Repenning, C. A., 1963, The chronologic and geographic range of desmostylians: Los Angeles County Mus. Contr. Sci., v. 78, p. 1-20.

Rothwell, W. T., Jr., 1965, Regional correlation of Pacific Coast Oligocene microfaunas: Am. Assoc. Petroleum Geologists Bull., v. 49, no. 10, p. 1766.

Turner, F. E., 1938, Stratigraphy and Mollusca of the marine Eocene of western Oregon: Geol. Soc. America, Spec. Paper 10, 130 p., 22 pls.

Washburne, C. W., 1914, Reconnaissance of the geology and oil prospects of northwestern Oregon : U.S. Geol. Survey Bull. 590, 111 p.

Weaver, C. E., 1943, Point Arena-Fort Ross area [California] : California Div. Mines Bull. 118, p. 628-632.

1944, Geology of the Cretaceous (Gualala Group) and Tertiary formations along the Pacific Coast between Point Arena and Fort Ross, California: Washington Univ. Pubs. Geology, v. 6, no. 1, 29 p.

Weaver, C. E., and others, 1944, Correlation of the marine Cenozoic formations of western North America : Geol. Soc. America Bull., v. 55, no. 5, p. 569-598.

Wentworth, C. M., 1966. The upper Cretaceous and lower Tertiary rocks of the Gualala area, northern Coast Ranges, California: Stanford, Calif., Stanford Univ. Ph. D. thesis. 
